
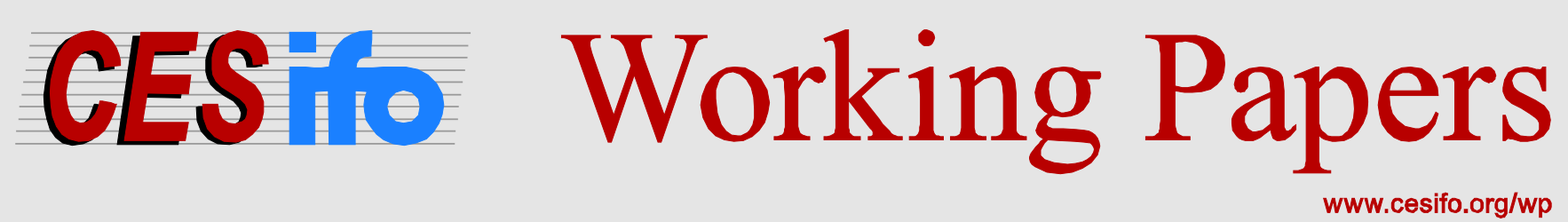

\title{
Does Legalization of Sunday Alcohol Sales Increase Crime?
}

\author{
Jungtaek Lee \\ Barış K. Yörük
}

\author{
CESIFO WORKING PAPER NO. 5065 \\ CATEgory 2: Public CHOICE \\ NOVEMBER 2014
}
An electronic version of the paper may be downloaded
- from the SSRN website:
- from the RePEc website:
- from the CESifo website:
wWw.SSRN.com
www.RePEc.org
www.CESifo-group.org/wp

\section{CESifo}




\title{
Does Legalization of Sunday Alcohol Sales Increase Crime?
}

\begin{abstract}
Recently, several states repealed their laws restricting the sale of alcohol on Sundays. We investigate the effect of this policy change on crime trends in seven states using data from FBI's National Incident-Based Reporting System (NIBRS). We identify the impact of the legalization of Sunday alcohol sales on several different types of criminal activity by exploiting the variation in the implementation of this policy change across different states at different times. Using difference-indifferences type models, we show that the repeal of the ban on Sunday alcohol sales is associated with significant increases in total property and violent crimes committed on Sundays. In particular, we find that states that legalized Sunday sales of alcohol experienced $13 \%$ to $20 \%$ increase in the total number of violent and property crimes committed on Sundays. However, the aggregate impact of this policy change on crimes committed on all days of the week is not significant due to either positive or statistically insignificant spillover effects of the repeal of Sunday alcohol sales bans on crimes committed on Mondays through Saturdays. These results are robust under alternative model specifications and several falsification tests.
\end{abstract}

JEL-Code: I180, K420.

Keywords: Sunday alcohol sales, alcohol consumption, criminal activity.

\author{
Jungtaek Lee* \\ Department of Economics \\ University at Albany, SUNY \\ 1400 Washington Ave \\ USA - Albany, NY 12222 \\ jlee21@albany.edu
}

\author{
Barış K. Yörük \\ Department of Economics \\ University at Albany, SUNY \\ 1400 Washington Ave \\ USA - Albany, NY 12222 \\ byoruk@albany.edu
}

*corresponding author

October 27, 2014

Barış K. Yörük acknowledges financial support by the National Institute on Alcohol Abuse and Alcoholism of National Institutes of Health under Award Number R03AA020636. The content of this paper is solely the responsibility of the authors and does not necessarily represent the official views of the National Institutes of Health. 


\section{Introduction}

While moderate alcohol consumption is generally linked with better health and longer life, the abuse of alcohol is often associated with many undesirable health outcomes. For instance, several studies document that heavy alcohol consumption is associated with low blood pressure, increased risk of stroke, liver diseases, and kidney failure. ${ }^{1}$ A large body of literature also documents considerable spillover effects of alcohol consumption on labor market outcomes, risky behavior, alcohol related traffic injuries and fatalities, and criminal activity. ${ }^{2}$ Given these direct and indirect effects of alcohol consumption, evaluating the effectiveness of the policies regulating alcohol availability and consumption is important and may help policymakers to make informed decisions about alcohol control policies.

Many studies have shown that policies that increase the full cost of consuming alcohol such as toughening drunk driving laws, raising alcohol taxes significantly, and imposing a minimum legal drinking age decrease alcohol consumption and may have positive spillover effects on alcohol consumption related outcomes. ${ }^{3}$ One of the widely-implemented forms of regulation on alcohol availability in the United States is restricting the Sunday sale of alcoholic beverages at off-premise locations, i.e., liquor stores and other locations where alcohol may be purchased but not consumed. Understanding the effect of the Sunday alcohol sales laws is particularly important since recently several states have repealed these laws, while removing the restriction on Sunday alcohol sales is a current policy debate in remaining states with such laws. On the one hand, proponents of Sunday sales argue that by allowing people to buy beer, wine, or liquor on Sundays at grocery or liquor stores, states can increase their tax revenue. On the other hand, opponents of such sales argue that removing bans on Sunday sales would increase alcohol consumption and hence, cause adverse public health consequences such as risky behavior.

Although the literature investigating the effect of Sunday alcohol sales ban in the United States is relatively limited, the existing studies find evidence that states that legalized sales of alcohol on Sundays experienced significant increases in alcohol consumption (Stehr, 2007 and Yörük, 2014a). Furthermore, several studies find that repealing restrictions on Sunday alcohol sales led to significant

\footnotetext{
${ }^{1}$ See, for example, Hansagi, et al. (1995) and Mann, et al. (2003).

${ }^{2}$ According to the National Highway Safety Administration, in 2008, 37 percent of traffic fatalities in the United States were alcohol related. In recent papers, Carpenter and Dobkin (2008) and Markowitz (2005) document the relationship between alcohol consumption and crime. Waddell (2012) links alcohol consumption to risky behaviors. Renna (2008) finds that alcohol consumption has a detrimental effect on employment.

${ }^{3}$ See, for example, Carpenter (2004), Yörük and Ertan Yörük (2011 and 2013), Crost and Rees (2013), Dee (1999), Markowitz (2005), Markowitz and Grossman (1998), Ertan Yörük and Yörük (2012 and 2015), Dills (2010), and Eisenberg (2003).
} 
increases in traffic accidents and fatalities occurred on Sundays (McMillan and Lapham, 2006; McMillan, Hanson, and Lapham, 2007). On the other hand, there exists an extensive literature which links alcohol consumption to increased criminal activity (Grönqvist and Niknami, 2014; Markowitz, 2005; Carpenter, 2007). These results suggest that the repeal of the restrictions on Sunday alcohol sales and hence, increased availability of alcohol may also have a significant impact on criminal activity.

In this paper, we investigate this hypothesis using detailed, day-specific crime data from National Incident-Based Reporting System (NIBRS) from 2000 to 2010 for seven states. We identify the impact of the legalization of Sunday alcohol sales on several different types of criminal activity by exploiting the variation in the implementation of this policy change across different states at different times. In particular, in contrast to few existing studies that investigated the effect of the Sunday alcohol laws on crime for a single state, our empirical analysis compares the changes in the number of crimes that are committed in the treatment states (Colorado, Delaware, and Massachusetts), after they repealed their Sunday alcohol sales ban with the number of crimes that are committed in the control states (Connecticut, South Carolina, Tennessee, Utah), which retained their Sunday alcohol sales ban during the time period considered. To our best knowledge, this paper is the first to use data from multiple states to investigate the effect of the repeal of Sunday alcohol sales ban on criminal activity.

Using difference-in-differences (DD) type models, we find that the repeal of the ban on Sunday alcohol sales is associated with significant increases in total violent and property crimes committed on Sundays. In particular, our findings suggest that states that legalized Sunday sales of alcohol experienced $13 \%$ to $20 \%$ increase in the total number of violent and property crimes committed on Sundays. However, the aggregate impact of this policy change on crimes committed on all days of the week is not significant due to either positive or statistically insignificant spillover effects of the repeal of Sunday alcohol sales bans on crimes committed on Mondays through Saturdays. Using dynamic DD models, we also show that the negative impact of removing restrictions on Sunday sales of alcohol on crimes committed on Sundays remains even in the long run. These results are robust under alternative model specifications and several falsification tests.

The remainder of this paper is organized as follows. The next section provides background information and a summary of the existing literature on the effect of the liberalization of alcohol sales on Sundays. Section 3 presents the data. Section 4 presents the empirical methodology. Section 5 discusses the results and provides several robustness checks. Section 6 interprets the results and concludes. 


\section{Background and literature review}

Blue laws, or restrictions on certain types of commerce only on Sundays have been widely implemented in the United States since the $17^{\text {th }}$ century. Laws prohibiting general retail activity on Sundays were still fairly widespread by the middle of the $20^{\text {th }}$ century. Following Supreme Court's decision in 1961, which states that blue laws could be found unconstitutional if their classification of prohibited activities rested on grounds wholly irrelevant to the achievement of the state's objective, several states started to repeal their blue laws. By the 1990s, blue laws in the United States were mainly limited to restrictions on off-premise alcohol sales (Gruber and Hungerman, 2008). Today, restrictions on Sunday alcohol sales is the only common form of blue law that was still being implemented in several states.

The literature investigating the effect of Sunday alcohol sales ban in the United States is relatively limited. Stehr (2007) finds that repeal of Sunday alcohol sales ban is associated with a $2.4 \%$ increase in total beer sales and a 3.5\% increase in total spirits sales. Yörük (2014a) shows that among the states that legalized Sunday sales of alcoholic beverages, Delaware, Pennsylvania, and New Mexico experienced significant increases in overall alcohol consumption. However, the effect of the legalization of Sunday alcohol sales in Massachusetts and Rhode Island on per capita alcohol consumption was insignificant. Recently, several countries including Canada, Sweden, and Australia repealed their laws restricting the sale of alcohol on certain days of the week. Carpenter and Eisenberg (2009) examine the effect of repealing Sunday alcohol sales ban on day-specific alcohol consumption in Ontario, Canada. They find that repealing Sunday alcohol sales ban is associated with a $7 \%$ to $15 \%$ increase in Sunday alcohol consumption. Smith $(1978,1987,1988$, and 1990) investigates the effect of repealing restriction on Sunday sales of alcohol at different cities of Australia. He finds that the repeal of these laws is significantly associated with increased alcohol consumption and traffic accidents on Sundays. Norstrom and Skog (2003 and 2005) and Olsson and Wikstrom (1982) show that alcohol consumption in Sweden was significantly increased after alcohol retail shops were allowed to operate on Saturdays. In a recent paper, Grönqvist and Niknami (2014) show that this policy change also leads to increase in crime rates.

Several studies investigate the effect of repealing Sunday alcohol sales ban on traffic accidents in the United States. On the one hand, McMillan and Lapham (2006) and McMillan, Hanson, and Lapham (2007) find very large increases in Sunday fatalities, using data on day-specific traffic fatalities in New Mexico. Stehr (2010) documents several limitations McMillan and Lapham (2006) and finds 
a far more modest effect of repealing the ban on the traffic fatalities. However, he also argues that compared to other states, the estimated effect of removing restriction on Sunday sales of alcohol on traffic accidents in New Mexico is considerably larger. Similarly, Lovenheim and Steefel (2011) find that restricting alcohol sales on Sunday has at most a small effect on fatal accident rates.

The literature contains several studies that examine the effect of alcohol control policies on crime. For instance, Markowitz (2005) finds that higher beer taxes decrease the probability of assault and alcohol or drug involved assault. Similarly, Markowitz and Grossman (1998) show that increasing the tax on beer can be an effective policy tool in reducing violence. Joksch and Jones (1993) investigate the effect of minimum legal drinking age on crime. Their findings imply that increasing minimum drinking age would lead to significant decrease in certain crimes such as vandalism and disorderly conduct. Carpenter (2007) examines the effect of zero tolerance laws on crime and documents that these laws lead to a decrease in property and nuisance crime arrests among youths, but no significant effects on violent crimes.

To our best knowledge, only two studies have investigated the relationship between Sunday alcohol sales ban and crime before. Both of these studies focus on a single state. Ligon, Thyer, and Lund (1996) find that partially removing a Sunday liquor sales ban in Athens, Georgia restaurants did not have a significant impact on driving under influence (DUI) arrests. Heaton (2012) investigates the impact of repealing Sunday alcohol sales ban on crime, using county-level policy changes in Virginia. Using data from the National Incident-Based Reporting System (NIBRS), he finds that the repeal of the Sunday alcohol sales ban in some counties of Virginia had no significant impact on violent, property and public order (drug law violation and weapon law violation) crimes. However, his results indicate a significant impact of the repeal of Sunday alcohol sales ban on disorderly conduct and alcohol-related serious crimes. Instead of focusing on a single state, in this paper, we estimate the effect of removing restrictions on Sunday sales of alcohol in multiple states, i.e., Colorado, Delaware, and Massachusetts. Heaton (2012) uses day-specific data to estimate the impact of Sunday alcohol sales on crime. His measure of day is a 24-hour period starting from 6 a.m. at any given day. This measure may be problematic since Sunday sales of alcohol generally starts at noon and continues until 5 p.m. to midnight at different states. ${ }^{4}$ Therefore, one would expect to observe the impact of the Sunday sales after 6 p.m. on Sundays. In this paper, instead of using the number of crimes committed during 24-hour periods, we use number of crimes committed during 12-hour periods as our outcome

\footnotetext{
${ }^{4}$ For instance, in New Mexico, Sunday sales of alcohol are allowed from noon to midnight at grocery stores whereas in Pennsylvania, alcohol can be purchased from noon to $5 \mathrm{pm}$ on Sundays at state-operated liquor stores.
} 
variable. In particular, our main interest is to estimate the effect of repealing Sunday alcohol sales ban on the number of crimes committed during the 12-hour period from 6 p.m. on Sundays to 6 a.m. on Mondays (hereafter, Sunday PM).

\section{Data}

We use data from the NIBRS from 2000 to 2010 to examine the effect of repealing Sunday alcohol sales ban on different types of crimes. ${ }^{5}$ The NIBRS contains very detailed information on each crime incident reported by police agencies (stations) registered in this system. These data include location and date of the incident, characteristics of the arrestee(s), offender(s), victim(s), and type and value of property stolen in connection with the crime. We restrict our sample to police stations that report crime occurrence for each month during 2000 - 2010 and cover cities or counties with a population of 25000 and more. ${ }^{6}$ We exclude crimes that occurred at bars or restaurants since Sunday alcohol laws regulate off-premise alcohol consumption. Since the minimum legal drinking age in the United States is 21 , we also exclude crimes that are committed by those who are younger than 21 . The NIBRS reports the exact time (hour and date) of each crime incident. Using this information, we calculate the number of crimes committed for every 12-hour period as reported by each policy station. Our main variable of interest is the number of different types of crimes committed on Sunday PMs.

The laws on Sunday alcohol sales in the United States are quite complex. During the analysis period $(2000-2010)$, Sunday alcohol sales were allowed in 27 states, 5 states repealed their laws restricting the sales of all types of alcohol on Sundays, and 11 states retained their restrictions on Sunday alcohol sales. The remaining 8 states had different policies towards Sunday sales. Most of them allowed beer and wine sales and allowed Sunday sales of spirits at the local level after a certain date. For instance, in Virginia, beer and wine sales on Sundays were legal but spirits sales were not. In 2004, few counties in Virginia started selling spirits on Sundays but in several counties of Virginia, spirits sales on Sundays are still not allowed. Our empirical analysis uses data from the states that repealed their laws restricting the sales of all types of alcohol on Sundays (treatment group) during $2000-2010$, and from the states that retained their Sunday alcohol law (control

\footnotetext{
${ }^{5}$ The NIBRS provides separate data on arrestees and offenders. We use data on arrestees since offender data suffer heavily from missing information.

${ }^{6}$ Participation to the NIBRS is voluntary and police stations may not report crime data at all or for certain time periods. In this paper, we include a policy station to our sample, if it reported crime data for each month during 2000-2010. The exception is data for Delaware. For this state, we consider 2001-2010 period due to the lack of data for 2000 .
} 
group) during the same period. Five states that removed their restrictions on Sunday sales of beer, wine, and spirits during 2000 - 2010 are Colorado, Delaware, Massachusetts, Rhode Island, and Pennsylvania. ${ }^{7}$ However, our treatment group includes only Colorado, Delaware, and Massachusetts due to the restrictions of the data. The participation to the NIBRS is voluntary and the number of police stations participating to the system varies by state, year, and month. The NIBRS does not provide daily crime data for Pennsylvania and provides data for Rhode Island only for $2005-2010$. Since Rhode Island repealed its Sunday alcohol sales ban in 2004, we exclude this state from our treatment group. Similarly, we cannot include Georgia, Illinois, Indiana, Minnesota, and Nebraska to our control group since the NIBRS does not report detailed crime data for these states. The NIBRS provides crime data from only one policy stations in Alabama and two policy stations in Oklahoma. We also exclude these states from the control group due to the very limited information. ${ }^{8}$ Therefore, our control group includes four states, namely Connecticut, South Carolina, Tennessee, and Utah. We report the number of police stations for each state, date of the repeal of Sunday alcohol sales ban for the treatment states, and the number of observations for each state in Appendix Table A1.

The NIBRS contains information on several different types of crimes. In this paper, we focus on serious violent and property crimes, which are labeled as Group A offenses in the NIBRS. ${ }^{9}$ Violent crimes include assault, vandalism, robbery, and forcible sex crimes, whereas the property crimes include larceny, motor vehicle theft (MVT), and burglary. For a falsification test, we also use data for forgery and fraud crimes to show that repealing Sunday alcohol sales ban does not have a significant impact on crimes that are not related to alcohol consumption. In Table 1, we provide the summary statistics for violent and property crimes committed on all days and on Sunday PMs for the full sample and separately for treatment and control states. In general, the average number of crimes committed on Sunday PMs is less than the average number of crimes committed on other days of the week. Except for assault and robbery, compared with the control states, the average number of crimes committed on Sunday PMs in treatment states is relatively higher.

\footnotetext{
${ }^{7}$ Treatment and control states are identified through Alcohol Policy Information System (APIS), Stehr (2010), and Yörük (2013).

${ }^{8}$ Including these states to our control group increases our sample size by only 8763 (less than 0.5 percent of the sample) and does not have a significant effect on our results.

${ }^{9}$ Group B crimes in the NIBRS are classified as minor crimes. We do not consider Group B crimes in our analysis since the NIBRS does not provide the exact time of incident for these type of crimes.
} 


\section{Methodology}

Several states repealed their Sunday alcohol sales bans at different times. We estimate the effect of repealing Sunday alcohol sales ban on criminal activity by exploiting this variation across different states. First, we use data on crimes committed on Sundays and employ a DD type model to compare changes in the number of crimes that are committed on Sunday PMs in the treatment states after they repealed their Sunday alcohol sales ban with the number of crimes that are committed on Sundays PMs in the control states, which still have a Sunday alcohol sales ban. Next, we use a similar model to estimate the spillover effects of the policy change on crimes committed on other days of the week and to assess the overall impact of the policy change on crime trends. Since the outcome variables are count variables, we report results from poisson and negative binomial models.

Our DD model can be expressed as follows:

$$
Y_{i s d m t}=\beta_{1}^{\prime} \mathbf{X}_{s t}+\lambda_{1} S B_{s d m t}+\theta_{i}+\mu_{s}+\gamma_{m}+\eta_{t}+\left(\text { trend } \times \mu_{s}\right)+e_{i s d m t},
$$

where $Y_{\text {isdmt }}$ is the number of certain type of crime committed in state $s$ on a particular 12-hour period $d$ in month $m$ of year $t$ as reported by police station $i$. In equation (1), $S B_{s d m t}$ is an indicator variable that is equal to 1 if Sunday alcohol sales were allowed in a state at a given date and $\mathbf{X}_{s t}$ is a set of state level control variables including log of total population, percentage of black, white, and Hispanic population, percentage of population who are between 15 and 19 age old, percentage of female population, unemployment rate, log of per capita income, poverty rate, percentage of high school and college graduates, percentage of high school dropouts, beer consumption per capita, beer tax, number of police officers per 1000 people, and an indicator variable that controls for whether or not the state governor is a democrat. ${ }^{10}$ Equation (1) also includes agency, state, month, and year fixed effects as denoted by $\theta_{i}, \mu_{s}, \gamma_{m}$, and $\eta_{t}$, respectively. In equation (1), the coefficient of interest is $\lambda_{1}$, which shows the impact of repealing restrictions on Sunday sales of alcohol on crimes committed on Sunday PMs.

The key identifying assumption in a DD type model is the common trends condition, which requires that in the absence of the repeal of Sunday alcohol sales ban in the treatment states, crime trends in treatment and control states would be similar. This assumption may fail in the presence of a

\footnotetext{
${ }^{10}$ The data for beer tax and beer consumption per capita come from Brewer's Almanac. The data for number of police officers are collected from Uniform Crime Reporting Data. We use data from the Council of State Governments, the National Governors' Association, and Elections Research Center in order to determine whether the state governor is a democrat or republican. The data for remaining control variables are collected from U.S. Census Bureau, Bureau of Labor Statistics, and Bureau of Economic Analysis.
} 
policy endogeneity problem. In particular, states that experienced relatively lower crime rates might be more likely to repeal the Sunday alcohol sales ban compared with those states with relatively higher crime rates. However, Figures 1 and 2 clearly show that these laws could not have been repealed as a reaction to decreased crime rates in the states that have repealed these laws. These figures plot the non-parametric kernel density of total number of violent and property crimes for treatment and control states over time. As illustrated in these figures, with an exception Massachusetts, trends in crime rates are fairly similar across states that removed restrictions on Sunday alcohol sales and those that did not prior to repeal of these laws. In Massachusetts, crime rate appears to have an increasing trend before the liberalization of Sunday alcohol sales instead of exhibiting a decreasing trend. Furthermore, In order to address concerns of policy endogeneity formally, we extend the basic DD analysis in two ways. First, we incorporate state-specific linear time trends $\left(\right.$ trend $\left.\times \mu_{s}\right)$ to equation (1) by interacting a dummy variable for each state with a time trend. These state-specific linear time trends control for a variety of other variables that are associated with crime trends that vary smoothly within states over time. Inclusion of the state trends also reduces concerns for potential omitted variables bias. Second, following (Gruber and Hungerman 2008) and Yörük (2014b), we estimate models that contain a dummy variable for one year before the effective date of the repeal of the Sunday alcohol sales ban in treatment states (placebo treatment). If the treatment dummy is just picking up a pre-existing decreasing or increasing trend in alcohol consumption and crime in the treatment states, then the placebo treatment dummy should be negative and significant (Gruber and Hungerman, 2008).

Following Carpenter (2004) and Yörük (2014b), we also extend the basic DD analysis and investigate the dynamic impact of repealing restrictions on Sunday alcohol sales on crime trends. In this model, we replace the treatment dummy with a series of time dummies for the years leading up to and after a state repeals its Sunday alcohol law. In all models, we adjust for potential serial correlation, within-state spatial correlation, and heterogeneity in errors by clustering the standard errors by state (Bertrand, Duflo, and Mullainathan. 2004).

\section{Results}

\section{$5.1 \quad$ Violent crimes}

In Table 2, we present DD estimates of the model for the effect of repealing Sunday alcohol sales ban on the number of crimes committed on Sunday PMs. The first specification reports the results from a poisson model. The results show that states that repealed their Sunday alcohol law experienced 
a significant increase in the total number of violent crimes. In particular, our model predicts that before the policy change, on average, 0.643 violent crimes were reported by a police station located at a treatment state on a random Sunday PM. The marginal impact of repealing the restrictions on Sunday alcohol sales is a 0.086 point increase in the number of violent crimes reported by each police station or alternatively, $13 \%$ increase in the total number of violent crimes compared with the period before the repeal. The second specification shows that this result is robust to the inclusion of state-specific linear time trends to the model. The third and fourth specifications replicate the same analysis using a negative binomial model. The results from these specifications are comparable to results from the poisson models and show that the total number of violent crimes increased by $12 \%$ to $16 \%$ in those states that repealed their restrictions on Sunday sales of alcohol.

In the remaining specifications, we investigate the effect of repealing Sunday alcohol sales ban on different types of violent crimes committed on Sunday PMs. The results indicate that the repeal of the Sunday alcohol law leads to an approximately $13 \%$ increase in assault in the treatment states. However, this effect is marginally significant at $10 \%$ significance level, only when the state-specific linear time trends are included in the model. The remaining results in Table 2 show that although the repeal of Sunday alcohol law did not have a significant impact on forcible sex, it significantly affected robbery and vandalism in the treatment states. In particular, states that repealed their Sunday alcohol law experienced a $16 \%$ to $18 \%$ decrease in robbery cases. However, results from alternative specifications show that compared with the control states, the policy change may also have increased the vandalism in the treatment states on Sunday PMs by up to $29 \%$.

\subsection{Property crimes}

Table 3 reports the estimates of the effect of the repeal of Sunday alcohol laws on property crimes committed on Sunday PMs. The results from more general specifications (the second and fourth specifications) that contain a state-specific linear time trends imply that compared with the control states, repealing restrictions on sale of alcohol on Sundays increased total property crimes committed on Sunday PMs in the treatment states by $20 \%$ to $23 \%$ (0.08 to 0.09 point increase in the number of property crimes reported by each police station at a random Sunday PM after the repeal).

The results reported in Table 3 also show that the increase in larceny after the repeal of Sunday alcohol laws is the main contributor of the increase in the total property crimes. Specifications that contain state-specific time trends show that after the repeal, compared with the control states, the number of larceny cases in the treatment states on Sunday PMs increased by $27 \%$ to $29 \%$. Similarly, 
repeal of the Sunday alcohol law led to a $12 \%$ to $15 \%$ increase in burglary and a $17 \%$ increase in MVT cases in the treatment states. However, these effects are marginally significant at $10 \%$ significance level.

\subsection{Falsification tests}

We run a series of falsification tests to check the robustness of our results. First, we estimate models that contain a dummy variable for one year before the effective date of the repeal of the Sunday alcohol sales ban in treatment states. If the treatment dummy is just picking up a pre-existing trend in alcohol consumption and crime, then the coefficient of the early treatment dummy should be statistically significant. The results reported in the fifth specification of Tables 2 and 3 clearly show that this is not the case. The coefficient on the placebo treatment is insignificant for all outcomes.

Next, we investigate the effect of the repeal of Sunday alcohol laws on two crime types that are supposedly not related to alcohol consumption: fraud and forgery. Table 4 shows that the marginal impact of the treatment on these outcomes is very small and statistically insignificant, which suggests that the removal of restrictions on Sunday alcohol sales did not have a significant impact on fraud and forgery in the treatment states.

Since the policy mainly aimed at increasing alcohol sales and hence, tax revenue on Sundays, the impact of the repeal of Sunday alcohol law on alcohol consumption on other days of the week should be relatively limited. We test this hypothesis and report the results in Table 5. As expected, when the outcome variables are different types of crimes committed on other days of the week, the coefficient on the treatment variable is mostly negative and statistically insignificant. The exceptions are total violent crimes committed on Tuesdays, Wednesdays, and Saturdays and robberies committed on Tuesdays and Saturdays. The results show that repeal of the Sunday alcohol law leads to significant decreases in total violent crimes and robberies committed on these days. The only negative spillover effect of the repeal of the ban appears to be on robberies committed on Fridays.

\subsection{Dynamic effects}

In Table 6, we investigate dynamic responses of different crime types to the repeal of Sunday alcohol sales ban. The estimates in this table are from a DD type model which instead of the treatment dummy, contains binary indicators for the years leading up to and after a state repeals its Sunday alcohol sales ban. For all crime types, the coefficient estimates on years before the policy change are relatively small and not statistically significant at conventional significance levels, which imply that 
states that repealed their ban did not remove the restrictions on Sunday alcohol sales as a response to significant changes in crime trends. On the other hand, except for MVT cases, Table 6 shows a significant increase in all crime types committed on Sunday PMs in the first year immediately following the repeal of the Sunday alcohol sales ban. Similarly, except for MVT, estimates for two to seven years since the repeal of the ban are uniformly positive and mostly statistically significant. Therefore, the negative impact of removing restrictions on Sunday sales of alcohol on crimes committed on Sunday PMs remains even in the long run.

\subsection{The aggregate impact of the repeal of bans}

So far we documented the negative impact of removing restrictions on Sunday sales of alcohol on crimes committed on Sunday PMs. However, we also showed that the spillover effects of the repeal of the Sunday alcohol sales ban on crimes committed on other days of the week are either positive or statistically insignificant. These results imply that aggregate effect the policy change on crimes committed on all days of the week might be positive or insignificant as well, In this section, we test this hypothesis by estimating equation (1) using data on crimes committed on all days of the week. Results reported in Table 7 show that total number of violent crimes and robberies decrease after the repeal of Sunday alcohol sales ban. However, this effect becomes statistically insignificant once the state-specific linear time trends are controlled for. The effect of the repeal of the ban on other violent crimes committed on all days of the week is statistically insignificant as well.

In Table 8, we replicate the same analysis using different types property crimes committed on all days of the week as outcome variables. The estimation results show that the impact of the repeal of Sunday alcohol sales ban on total property crimes and burglaries committed on all days of the week is negative. However, similar to the results provided in Table 7, this effect is not robust to the inclusion of state-specific linear time trends to the model. The effect of the policy change on the remaining outcomes is also negative but statistically insignificant.

\section{Conclusion}

In this paper, we investigate the effect of the legalization of Sunday alcohol sales on Sundays on several different types of violent and property crimes using very detailed, day-specific crime data from NIBRS for seven states. Although two previous studies investigated the relationship between Sunday alcohol laws and criminal activity, both of these studies focus on a single state. To our best 
knowledge, this paper is the first to use data from multiple states to investigate the effect of the repeal of Sunday alcohol sales ban on criminal activity. Furthermore, we provide a more refined empirical analysis by utilizing detailed crime data for each 12 hour period, which is reported at the police station level. Using DD type models which control for state, time, and policy station fixed effects, we find that the legalization of Sunday alcohol sales is associated with significant increases in total violent and property crimes committed on Sundays. In particular, our findings imply that states that removed restrictions on Sunday sales of alcohol experienced $13 \%$ to $20 \%$ increase in the total number of violent and property crimes committed on Sundays. However, we also show that the aggregate impact of this policy change on crimes committed on all days of the week is not significant due to either positive or statistically insignificant spillover effects of the repeal of Sunday alcohol sales bans on crimes committed on Mondays through Saturdays. Using dynamic DD models, we also find that the negative impact of removing restrictions on Sunday sales of alcohol on crimes committed on Sundays remains even in the long run. Our results are robust under alternative model specifications and several falsification tests.

These findings are particularly important given the ongoing public policy debates about the relevancy of the restrictions on Sunday sales of alcohol at off-premise locations. Although we were not able to employ data for all states due to the limitations of the existing crime data, we find evidence that the negative effects of legalizing Sunday alcohol sales on criminal activity is day specific and the overall crime trends are not affected by this policy change. Our result is in line with that of Lovenheim and Steefel (2011), who find that the aggregate impact of restricting alcohol sales on Sunday has at most a small effect on fatal accident rates. One likely reason for these results is the possibility that individuals adjust their daily alcohol consumption or purchase patterns after the legalization of Sunday alcohol sales at off-premise locations by drinking or purchasing more on Sundays but less on the other days of the week. However, this hypothesis is not testable since the current data sets on alcohol consumption in the United States do not contain information on day-specific alcohol consumption patterns. Therefore, further research is needed to investigate the effects of the Sunday alcohol law on crime and other alcohol consumption related outcomes. This calls for collection of detailed, day-specific data on alcohol consumption and alcohol consumption related outcomes. 


\section{References}

[1] Bertrand, M., E. Duflo, and S. Mullainathan, 2004, How much should we trust differences-indifferences estimates?, Quarterly Journal of Economics, 119, 249-275.

[2] Carpenter, C., 2004, How do zero tolerance drunk driving laws work?, Journal of Health Economics, 23, 61-83.

[3] Carpenter, C., 2007, Heavy alcohol use and crime: Evidence from underage drunk-driving laws, Journal of Law and Economics, 50, 539-557.

[4] Carpenter, C.S. and D. Eisenberg, 2009, Effects of Sunday sales restrictions on overall and dayspecific alcohol consumption: Evidence from Canada, Journal of Studies on Alcohol and Drugs, 70, 126-133.

[5] Carpenter, C. and C. Dobkin, forthcoming, The minimum legal drinking age and crime, forthcoming, Review of Economics and Statistics.

[6] Crost, B. and D. Rees, 2013, The minimum legal drinking age and marijuana use: New estimates from the NLSY97, Journal of Health Economics, 32, 474-476.

[7] Dee, T.S., 1999, State alcohol policies, teen drinking and traffic fatalities, Journal of Public Economics, 72, 289-315.

[8] Dills, A., 2010, Social host liability for minors and underage drunk-driving accidents, Journal of Health Economics, 29, 241-249.

[9] Eisenberg, D., 2003, Evaluating the effectiveness of policies related to drunk driving, Journal of Policy Analysis and Management, 22, 249-274.

[10] Ertan Yörük, C. and B.K. Yörük, 2012, The impact of drinking on psychological well-being: Evidence from minimum drinking age laws in the United States, Social Science and Medicine, $75,1844-1854$.

[11] Ertan Yörük, C. and B.K. Yörük, 2015, Alcohol consumption and risky sexual behavior among young adults: Evidence from minimum legal drinking age laws, forthcoming in Journal of Population Economics. 
[12] Gröqvist, H. and S. Niknami, 2014, Alcohol availability and crime: Lessons from liberalized weekend sales restrictions, Journal of Urban Economics, 81, 77-84.

[13] Gruber, J, and D. Hungerman, 2008, The Church vs. the Mall: What Happens When Religion Faces Increased Secular Competition?, Quarterly Journal of Economics, 123, 831-862.

[14] Hansagi, H., et al., 1995, Alcohol consumption and stroke mortality, Stroke, 26, 1768-1773.

[15] Heaton, P, 2012, Sunday liquor laws and crime, Journal of Public Economics, 96, 42-52.

[16] Joksch, H.C. and R.K. Jones, 1993, Changes in the Drinking Age and Crime, Journal of Criminal Justice, 21, 209-221.

[17] Ligon, J., B.A. Thyer, and R. Lund, 1996, Drinking, eating, and driving: Evaluating the effects of partially removing a Sunday liquor sales ban, Journal of Alcohol and Drug Education, 42, $15-24$.

[18] Lovenheim, M.F. and D.P. Steefel, 2011, Do blue laws save lives? The effect of Sunday alcohol sales bans on fatal vehicle accidents, Journal of Policy Analysis and Management, 30, 798-820.

[19] Mann, R.E., R.G. Smart, R. Govoni, 2003, The epidemiology of alcoholic liver disease, Alcohol Research \& Health, 27, 209-219.

[20] Markowitz, S. and M. Grossman, 1998, Alcohol regulation and domestic violence towards children, Contemporary Economic Policy, 16, 309-320.

[21] Markowitz, S., 2005, Alcohol, drugs and violent crime, International Review of Law and Economics, 25, 20-44.

[22] McMillan G.P. and S.C. Lapham, 2006, Effectiveness of bans and laws in reducing traffic deaths: Legalized Sunday packaged alcohol sales and alcohol-related traffic crashes and crash fatalities in New Mexico, American Journal of Public Health, 96, 1944-1948.

[23] McMillan G.P., T.E. Hanson, and S.C. Lapham, 2007, Geographic variability in alcohol-related crashes in response to legalized Sunday packaged alcohol sales in New Mexico, Accident Analysis and Prevention, 39, 252-257.

[24] Norstrom, T. and O.J. Skog, 2003, Saturday opening of alcohol retail shops in Sweden: An impact analysis, Journal of Studies on Alcohol, 64, 393-401. 
[25] Norstrom, T. and O.J. Skog, 2005, Saturday opening of alcohol retail shops in Sweden: an experiment in two phases, Addiction, 100, 767-76.

[26] Olsson, O. and P.H. Wikstrom, 1982, Effects of the experimental Saturday closing of liquor retail stores in Sweden, Contemporary Drug Problems,11, 325-353.

[27] Renna, F., 2008, Alcohol abuse, alcoholism, and labor market outcomes: Looking for the missing link, Industrial and Labor Relations Review, 62, 92-103.

[28] Smith, D.I., 1978, Impact on traffic safety of the introduction of Sunday alcohol sales in Perth, Western Australia, Journal of Studies on Alcohol, 39, 1302-1304.

[29] Smith, D.I., 1987, Effect on traffic accidents of introducing Sunday hotel sales in New South Wales, Australia, Contemporary Drug Problems, 14, 279-294.

[30] Smith, D.I., 1988, Effect on traffic accidents on introducing Sunday alcohol sales in Brisbane, Australia, International Journal of Addictions, 23, 1901-1909.

[31] Smith, D.I., 1990, Effect on casualty traffic accidents of changing Sunday alcohol sales legislation in Victoria, Australia, The Journal of Drug Issues, 20, 417-426.

[32] Stehr, M., 2007, The effect of Sunday sales bans and excise taxes on drinking and cross-border shopping for alcoholic beverages, National Tax Journal, 60, 85-105.

[33] Stehr, M, 2010, The effect of Sunday sales of alcohol on highway crash fatalities, The B.E. Journal of Economic Analysis 6 Policy (Topics), 10, Article 73.

[34] Waddell, G.R., 2012, Gender and the influence of peer alcohol consumption on adolescent sexual activity, Economic Inquiry, 50, 248-263.

[35] Yörük, B.K. and C. Ertan Yörük, 2011, The impact of minimum legal drinking age laws on alcohol consumption, smoking, and marijuana use: Evidence from a regression discontinuity design using exact date of birth, Journal of Health Economics, 30, 740-752.

[36] Yörük, B.K. and C. Ertan Yörük, 2013, The impact of minimum legal drinking age laws on alcohol consumption, smoking, and marijuana use revisited, Journal of Health Economics, 32, 477-479. 
[37] Yörük, B.K., 2014a, Legalization of Sunday alcohol sales and alcohol consumption in the United States, Addiction, 109, 55-61.

[38] Yörük, B.K., 2014b, Can technology help to reduce underage drinking? Evidence from false ID laws with scanner provision, Journal of Health Economics, 36, 33-46. 
Table 1. Summary statistics for violent and property crimes

\begin{tabular}{|c|c|c|c|c|c|c|}
\hline & \multicolumn{2}{|c|}{ Full sample } & \multicolumn{2}{|c|}{ Treatment states } & \multicolumn{2}{|c|}{ Control states } \\
\hline & All days & Sunday PM & All days & Sunday PM & All days & Sunday PM \\
\hline \multicolumn{7}{|l|}{ Violent crimes } \\
\hline Assault & $\begin{array}{c}0.782 \\
(1.390)\end{array}$ & $\begin{array}{c}0.564 \\
(1.099)\end{array}$ & $\begin{array}{c}0.719 \\
(1.245)\end{array}$ & $\begin{array}{c}0.536 \\
(1.045)\end{array}$ & $\begin{array}{c}0.811 \\
(1.452)\end{array}$ & $\begin{array}{c}0.578 \\
(1.124)\end{array}$ \\
\hline Robbery & $\begin{array}{c}0.048 \\
(0.276)\end{array}$ & $\begin{array}{c}0.040 \\
(0.248)\end{array}$ & $\begin{array}{c}0.050 \\
(0.265)\end{array}$ & $\begin{array}{c}0.039 \\
(0.228)\end{array}$ & $\begin{array}{c}0.047 \\
(0.279)\end{array}$ & $\begin{array}{c}0.040 \\
(0.257)\end{array}$ \\
\hline Vandalism & $\begin{array}{c}0.401 \\
(0.917)\end{array}$ & $\begin{array}{c}0.284 \\
(0.787)\end{array}$ & $\begin{array}{c}0.529 \\
(1.093)\end{array}$ & $\begin{array}{c}0.363 \\
(0.900)\end{array}$ & $\begin{array}{c}0.341 \\
(0.814)\end{array}$ & $\begin{array}{c}0.246 \\
(0.723)\end{array}$ \\
\hline Forcible sex & $\begin{array}{c}0.035 \\
(0.207)\end{array}$ & $\begin{array}{c}0.023 \\
(0.165)\end{array}$ & $\begin{array}{c}0.042 \\
(0.221)\end{array}$ & $\begin{array}{c}0.028 \\
(0.178)\end{array}$ & $\begin{array}{c}0.032 \\
(0.200)\end{array}$ & $\begin{array}{c}0.021 \\
(0.158)\end{array}$ \\
\hline Total violent crimes & $\begin{array}{c}1.266 \\
(1.976)\end{array}$ & $\begin{array}{c}0.911 \\
(1.597)\end{array}$ & $\begin{array}{c}1.340 \\
(1.991)\end{array}$ & $\begin{array}{c}0.966 \\
(1.648)\end{array}$ & $\begin{array}{c}1.232 \\
(1.967)\end{array}$ & $\begin{array}{c}0.885 \\
(1.574)\end{array}$ \\
\hline \multicolumn{7}{|l|}{ Property crimes } \\
\hline Larceny & $\begin{array}{c}0.851 \\
(1.642)\end{array}$ & $\begin{array}{c}0.670 \\
(1.262)\end{array}$ & $\begin{array}{c}0.899 \\
(1.794)\end{array}$ & $\begin{array}{c}0.403 \\
(1.002)\end{array}$ & $\begin{array}{c}0.828 \\
(1.564)\end{array}$ & $\begin{array}{c}0.419 \\
(0.932)\end{array}$ \\
\hline MVT & $\begin{array}{c}0.103 \\
(0.396)\end{array}$ & $\begin{array}{c}0.075 \\
(0.334)\end{array}$ & $\begin{array}{c}0.134 \\
(0.481)\end{array}$ & $\begin{array}{c}0.094 \\
(0.399)\end{array}$ & $\begin{array}{c}0.089 \\
(0.347)\end{array}$ & $\begin{array}{c}0.066 \\
(0.297)\end{array}$ \\
\hline Burglary & $\begin{array}{c}0.238 \\
(0.641)\end{array}$ & $\begin{array}{c}0.140 \\
(0.451)\end{array}$ & $\begin{array}{c}0.255 \\
(0.679)\end{array}$ & $\begin{array}{c}0.151 \\
(0.474)\end{array}$ & $\begin{array}{c}0.230 \\
(0.622)\end{array}$ & $\begin{array}{c}0.135 \\
(0.439)\end{array}$ \\
\hline Total property crimes & $\begin{array}{c}1.192 \\
(2.129)\end{array}$ & $\begin{array}{c}0.630 \\
(1.276)\end{array}$ & $\begin{array}{l}1.288 \\
(2.394)\end{array}$ & $\begin{array}{c}0.648 \\
(1.404)\end{array}$ & $\begin{array}{c}1.146 \\
(1.990)\end{array}$ & $\begin{array}{c}0.621 \\
(1.210)\end{array}$ \\
\hline Number of obs. & 1746249 & 166293 & 561720 & 53501 & 1184529 & 112792 \\
\hline
\end{tabular}

Notes: The average number of crimes reported by each police station for each 12-hour period is presented in columns 1,3 , and 5 . The average number of crimes reported by each police station for each 12 -hour period between Sunday $6 \mathrm{pm}$ and Monday 6 am is presented in columns 2, 4, and 6 . Standard deviations are presented in parenthesis. 
Table 2. The effect of the repeal of Sunday alcohol bans on violent crimes

\begin{tabular}{lccccc}
\hline Total Violent & $(1)$ & $(2)$ & $(3)$ & $(4)$ & $(5)$ \\
\hline Treatment & $0.125^{* * *}$ & $0.151^{* * *}$ & $0.117^{* * *}$ & $0.149^{* * *}$ & \\
& $(0.048)$ & $(0.046)$ & $(0.048)$ & $(0.048)$ & \\
Marginal Effect for Treatment & $0.086^{* *}$ & $0.104^{* * *}$ & $0.080^{* *}$ & $0.103^{* * *}$ & \\
& $(0.034)$ & $(0.032)$ & $(0.034)$ & $(0.034)$ & \\
Predicted Number of Crimes & 0.643 & 0.640 & 0.645 & 0.641 & \\
Incidence Rate Ratio & 1.134 & 1.163 & 1.124 & 1.160 & \\
Placebo Treatment & & & & & -0.037 \\
& & & & & $(0.038)$ \\
Assault & & & & &
\end{tabular}

\begin{tabular}{lcccc}
\hline Treatment & 0.124 & $0.127^{*}$ & 0.130 & $0.129^{*}$ \\
& $(0.075)$ & $(0.069)$ & $(0.082)$ & $(0.077)$ \\
Marginal Effect for Treatment & 0.051 & $0.052^{*}$ & 0.053 & 0.053 \\
& $(0.032)$ & $(0.029)$ & $(0.035)$ & $(0.033)$
\end{tabular}

$\begin{array}{lllll}\text { Predicted Number of Crimes } & 0.385 & 0.385 & 0.385 & 0.385\end{array}$

$\begin{array}{lllll}\text { Incidence Rate Ratio } & 1.132 & 1.135 & 1.139 & 1.137\end{array}$

Placebo Treatment $\quad-0.085$

$(0.057)$

Forcible Sex

\begin{tabular}{lccccc}
\hline Treatment & -0.010 & -0.081 & -0.005 & -0.085 & \\
& $(0.089)$ & $(0.053)$ & $(0.092)$ & $(0.056)$ & \\
Marginal Effect for Treatment & -0.000 & -0.001 & 0.000 & -0.001 & \\
& $(0.001)$ & $(0.001)$ & $(0.001)$ & $(0.001)$ & \\
Predicted Number of Crimes & 0.011 & 0.012 & 0.011 & 0.011 & \\
Incidence Rate Ratio & 0.991 & 0.922 & 0.996 & 0.919 & -0.017 \\
Placebo Treatment & & & & & \\
& & & & & \\
Robbery & & & & & \\
\hline Treatment & $-0.170^{* *}$ & -0.158 & $-0.198^{* * *}$ & -0.186 & \\
& $(0.072)$ & $(0.133)$ & $(0.065)$ & $(0.119)$ & \\
Marginal Effect for Treatment & $-0.002^{* *}$ & -0.002 & $-0.003^{* * *}$ & $-0.002^{*}$ & \\
& $(0.001)$ & $(0.002)$ & $(0.001)$ & $(0.001)$ & \\
Predicted Number of Crimes & 0.015 & 0.015 & 0.014 & 0.014 & \\
Incidence Rate Ratio & 0.843 & 0.854 & 0.820 & 0.830 & \\
Placebo Treatment & & & & & \\
& & & & & \\
& & & & & \\
& & & & & \\
\end{tabular}




\begin{tabular}{lccccc}
\hline Treatment & $0.209^{* * *}$ & $0.255^{* * *}$ & $0.155^{* *}$ & $0.235^{* * *}$ & \\
& $(0.071)$ & $(0.046)$ & $(0.067)$ & $(0.047)$ & \\
Marginal Effect for Treatment & $0.041^{* * *}$ & $0.050^{* * *}$ & $0.030^{* *}$ & $0.046^{* * *}$ & \\
& $(0.015)$ & $(0.010)$ & $(0.013)$ & $(0.010)$ & \\
Predicted Number of Crimes & 0.175 & 0.174 & 0.176 & 0.173 & \\
Incidence Rate Ratio & 1.233 & 1.290 & 1.167 & 1.265 & \\
Placebo Treatment & & & & & 0.065 \\
& & & & & \\
& No & Yes & No & Yes & Yes \\
State-specific linear time trend & & & Negative & Negative & Negative \\
Model & Poisson & Poisson & Binomial & Binomial & Binomial \\
\hline
\end{tabular}

Notes: The number of observations in all specifications is 166293. All regressions include full set of control variables and month, year, state, and police station fixed effects as discussed in the text. Predicted number of crimes is calculated for the treatment states before the repeal of the restrictions on Sunday alcohol sales. Standard errors are clustered at the state level and reported in parenthesis. The signs *, **, and ${ }^{* * *}$ denote statistical significance at 10,5 , and 1 percent significance levels, respectively. 
Table 3. The effect of the repeal of Sunday alcohol bans on property crimes

\begin{tabular}{lccccc}
\hline Total Property & $(1)$ & $(2)$ & $(3)$ & $(4)$ & $(5)$ \\
\hline Treatment & 0.043 & $0.184^{* * *}$ & 0.064 & $0.204^{* * *}$ & \\
& $(.054)$ & $(0.044)$ & $(0.050)$ & $(0.043)$ & \\
Marginal Effect for Treatment & 0.019 & $0.084^{* * *}$ & 0.028 & $0.094^{* * *}$ & \\
& $(0.024)$ & $(0.021)$ & $(0.023)$ & $(0.021)$ & \\
Predicted Number of Crimes & 0.430 & 0.418 & 0.431 & 0.418 & \\
Incidence Rate Ratio & 1.044 & 1.201 & 1.066 & 1.226 & \\
Placebo Treatment & & & & & 0.058 \\
& & & & & $0.153)$ \\
Larceny & & & & &
\end{tabular}

\begin{tabular}{|c|c|c|c|c|c|}
\hline Treatment & $\begin{array}{l}0.083^{*} \\
(0.050)\end{array}$ & $\begin{array}{c}0.238^{* * *} \\
(0.040)\end{array}$ & $\begin{array}{l}0.093^{*} \\
(0.052)\end{array}$ & $\begin{array}{c}0.253^{* * *} \\
(0.044)\end{array}$ & \\
\hline Marginal Effect for Treatment & $\begin{array}{c}0.024 \\
(0.015)\end{array}$ & $\begin{array}{c}0.071^{* * *} \\
(0.013)\end{array}$ & $\begin{array}{l}0.027^{*} \\
(0.015)\end{array}$ & $\begin{array}{c}0.077^{* * *} \\
(0.014)\end{array}$ & \\
\hline Predicted Number of Crimes & 0.274 & 0.266 & 0.275 & 0.266 & \\
\hline $\begin{array}{l}\text { Incidence Rate Ratio } \\
\text { Placebo Treatment }\end{array}$ & 1.086 & 1.269 & 1.097 & 1.288 & $\begin{array}{c}0.084 \\
(0.152)\end{array}$ \\
\hline \multicolumn{6}{|l|}{ Burglary } \\
\hline Treatment & $\begin{array}{l}-0.012 \\
(0.065)\end{array}$ & $\begin{array}{l}0.116^{*} \\
(0.062)\end{array}$ & $\begin{array}{c}0.006 \\
(0.060)\end{array}$ & $\begin{array}{c}0.137 * * \\
(0.059)\end{array}$ & \\
\hline Marginal Effect for Treatment & $\begin{array}{l}-0.001 \\
(0.006)\end{array}$ & $\begin{array}{l}0.012^{*} \\
(0.006)\end{array}$ & $\begin{array}{c}0.001 \\
(0.006)\end{array}$ & $\begin{array}{c}0.014^{* *} \\
(0.006)\end{array}$ & \\
\hline $\begin{array}{l}\text { Predicted Number of Crimes } \\
\text { Incidence Rate Ratio } \\
\text { Placebo Treatment }\end{array}$ & $\begin{array}{l}0.097 \\
0.988\end{array}$ & $\begin{array}{l}0.095 \\
1.122\end{array}$ & $\begin{array}{l}0.096 \\
1.006\end{array}$ & $\begin{array}{l}0.094 \\
1.147\end{array}$ & $\begin{array}{l}-0.095 \\
(0.130)\end{array}$ \\
\hline \multicolumn{6}{|l|}{$M V T$} \\
\hline Treatment & $\begin{array}{c}0.092 \\
(0.087)\end{array}$ & $\begin{array}{l}0.157^{*} \\
(0.089)\end{array}$ & $\begin{array}{c}0.101 \\
(0.093)\end{array}$ & $\begin{array}{l}0.153^{*} \\
(0.089)\end{array}$ & \\
\hline Marginal Effect for Treatment & $\begin{array}{c}0.003 \\
(0.003)\end{array}$ & $\begin{array}{l}0.006^{*} \\
(0.003)\end{array}$ & $\begin{array}{c}0.004 \\
(0.003)\end{array}$ & $\begin{array}{c}0.005 \\
(0.003)\end{array}$ & \\
\hline Predicted Number of Crimes & 0.036 & 0.034 & 0.034 & 0.032 & \\
\hline Incidence Rate Ratio & 1.096 & 1.170 & 1.106 & 1.165 & \\
\hline Placebo Treatment & & & & & $\begin{array}{c}0.067 \\
(0.249)\end{array}$ \\
\hline
\end{tabular}




\begin{tabular}{lccccc}
\hline State-specific linear time trend & No & Yes & No & Yes & Yes \\
\multirow{2}{*}{ Model } & & & Negative & Negative & Negative \\
& Poisson & Poisson & Binomial & Binomial & Binomial \\
\hline
\end{tabular}

Notes: The number of observations in all specifications is 166293. All regressions include full set of control variables and month, year, state, and police station fixed effects as discussed in the text. Predicted number of crimes is calculated for the treatment states before the repeal of the restrictions on Sunday alcohol sales. Standard errors are clustered at the state level and reported in parenthesis. The signs *, **, and ${ }^{* * *}$ denote statistical significance at 10,5, and 1 percent significance levels, respectively. 
Table 4. The effect of the repeal of Sunday alcohol bans on fraud and forgery: Falsification test

\begin{tabular}{lcccc}
\hline Fraud & $(1)$ & $(2)$ & $(3)$ & $(4)$ \\
\hline Treatment & -0.076 & -0.062 & -0.047 & -0.008 \\
& $(0.060)$ & $(0.068)$ & $(0.062)$ & $(0.074)$ \\
Marginal Effect for Treatment & -0.001 & -0.001 & -0.001 & -0.000 \\
& $(0.001)$ & $(0.001)$ & $(0.001)$ & $(0.001)$ \\
Predicted Number of Crimes & 0.019 & 0.016 & 0.017 & 0.015 \\
Incidence Rate Ratio & 0.923 & 0.934 & 0.954 & 0.993 \\
Forgery & & & & \\
\hline Treatment & -0.033 & 0.110 & -0.045 & 0.101 \\
& $(0.172)$ & $(0.210)$ & $(0.166)$ & $(0.212)$ \\
Marginal Effect for Treatment & -0.000 & 0.001 & -0.000 & 0.001 \\
& $(0.002)$ & $(0.002)$ & $(0.001)$ & $(0.002)$ \\
Predicted Number of Crimes & 0.009 & 0.009 & 0.009 & 0.008 \\
Incidence Rate Ratio & 0.968 & 1.117 & 0.956 & 1.106 \\
\hline State-specific linear time trend & No & Yes & No & Yes \\
Model & Poisson & Poisson & Begative & Negative \\
\hline
\end{tabular}

Notes: The number of observations in all specifications is 166293. All regressions include full set of control variables and month, year, state, and police station fixed effects as discussed in the text. Predicted number of crimes is calculated for the treatment states before the repeal of the restrictions on Sunday alcohol sales. Standard errors are clustered at the state level and reported in parenthesis. 
Table 5. The effect of the repeal of Sunday alcohol bans on crimes committed on other days of the week

\begin{tabular}{|c|c|c|c|c|c|c|}
\hline & Mon & Tues & Wed & Thur & Fri & Sat \\
\hline \multicolumn{7}{|c|}{ Total Violent } \\
\hline Treatment & $\begin{array}{l}-0.086 \\
(0.052)\end{array}$ & $\begin{array}{c}-0.059^{* *} \\
(0.024)\end{array}$ & $\begin{array}{c}-0.076^{*} \\
(0.042)\end{array}$ & $\begin{array}{l}-0.046 \\
(0.042)\end{array}$ & $\begin{array}{l}-0.031 \\
(0.053)\end{array}$ & $\begin{array}{c}-0.101^{*} \\
(0.056)\end{array}$ \\
\hline \multicolumn{7}{|l|}{ Assault } \\
\hline Treatment & $\begin{array}{c}-0.078 \\
(0.065) \\
\end{array}$ & $\begin{array}{c}-0.057 \\
(0.032) \\
\end{array}$ & $\begin{array}{c}-0.036 \\
(0.047) \\
\end{array}$ & $\begin{array}{c}-0.053 \\
(0.058) \\
\end{array}$ & $\begin{array}{r}-0.040 \\
(0.068) \\
\end{array}$ & $\begin{array}{r}-0.100 \\
(0.064) \\
\end{array}$ \\
\hline \multicolumn{7}{|l|}{ Robbery } \\
\hline Treatment & $\begin{array}{c}0.046 \\
(0.059) \\
\end{array}$ & $\begin{array}{c}-0.121^{* * *} \\
(0.044) \\
\end{array}$ & $\begin{array}{c}-0.103 \\
(0.070) \\
\end{array}$ & $\begin{array}{c}0.019 \\
(0.065) \\
\end{array}$ & $\begin{array}{c}0.123^{* *} \\
(0.062)\end{array}$ & $\begin{array}{c}-0.149 * * \\
(0.061) \\
\end{array}$ \\
\hline \multicolumn{7}{|c|}{ Forcible Sex } \\
\hline Treatment & $\begin{array}{c}0.079 \\
(0.076) \\
\end{array}$ & $\begin{array}{c}0.116 \\
(0.107) \\
\end{array}$ & $\begin{array}{c}-0.033 \\
(0.036) \\
\end{array}$ & $\begin{array}{c}0.124 \\
(0.081) \\
\end{array}$ & $\begin{array}{c}0.027 \\
(0.097) \\
\end{array}$ & $\begin{array}{c}0.002 \\
(0.057) \\
\end{array}$ \\
\hline \multicolumn{7}{|l|}{ Vandalism } \\
\hline Treatment & $\begin{array}{c}-0.095 \\
(0.065) \\
\end{array}$ & $\begin{array}{c}-0.052 \\
(0.054) \\
\end{array}$ & $\begin{array}{r}-0.099 \\
(0.079) \\
\end{array}$ & $\begin{array}{c}-0.024 \\
(0.061) \\
\end{array}$ & $\begin{array}{r}-0.008 \\
(0.058) \\
\end{array}$ & $\begin{array}{r}-0.084 \\
(0.071) \\
\end{array}$ \\
\hline \multicolumn{7}{|c|}{ Total Property } \\
\hline Treatment & $\begin{array}{c}-0.038 \\
(0.070) \\
\end{array}$ & $\begin{array}{c}-0.017 \\
(0.070) \\
\end{array}$ & $\begin{array}{c}-0.039 \\
(0.079) \\
\end{array}$ & $\begin{array}{c}0.001 \\
(0.083) \\
\end{array}$ & $\begin{array}{c}-0.022 \\
(0.079) \\
\end{array}$ & $\begin{array}{c}-0.025 \\
(0.077) \\
\end{array}$ \\
\hline \multicolumn{7}{|l|}{ Larceny } \\
\hline Treatment & $\begin{array}{c}-0.049 \\
(0.079) \\
\end{array}$ & $\begin{array}{c}-0.009 \\
(0.082) \\
\end{array}$ & $\begin{array}{c}-0.054 \\
(0.087) \\
\end{array}$ & $\begin{array}{c}0.010 \\
(0.088) \\
\end{array}$ & $\begin{array}{c}-0.029 \\
(0.080) \\
\end{array}$ & $\begin{array}{r}-0.018 \\
(0.078) \\
\end{array}$ \\
\hline \multicolumn{7}{|l|}{ Burglary } \\
\hline Treatment & $\begin{array}{c}0.009 \\
(0.070)\end{array}$ & $\begin{array}{c}-0.032 \\
(0.050)\end{array}$ & $\begin{array}{c}0.020 \\
(0.087)\end{array}$ & $\begin{array}{c}-0.032 \\
(0.075)\end{array}$ & $\begin{array}{l}-0.015 \\
(0.077)\end{array}$ & $\begin{array}{c}-0.053 \\
(0.069)\end{array}$ \\
\hline \multicolumn{7}{|l|}{$M V T$} \\
\hline Treatment & $\begin{array}{c}0.007 \\
(0.061) \\
\end{array}$ & $\begin{array}{c}0.058 \\
(0.070) \\
\end{array}$ & $\begin{array}{c}0.060 \\
(0.053) \\
\end{array}$ & $\begin{array}{c}0.047 \\
(0.083) \\
\end{array}$ & $\begin{array}{c}0.100 \\
(0.072) \\
\end{array}$ & $\begin{array}{c}0.011 \\
(0.128) \\
\end{array}$ \\
\hline
\end{tabular}

Notes: Results from negative binomial models are reported. The number of observations in all models is 249477. All regressions include full set of control variables and month, year, state, and police station fixed effects as discussed in the text. Standard errors are clustered at the state level and reported in parenthesis. The signs ${ }^{*},{ }^{* *}$, and ${ }^{* * *}$ denote statistical significance at 10,5 , and 1 percent significance levels, respectively. 
Table 6. Dynamic effects of the repeal of Sunday alcohol bans

\begin{tabular}{|c|c|c|c|c|c|c|c|}
\hline & $\begin{array}{c}\text { Total } \\
\text { Violent }\end{array}$ & Assault & Vandalism & $\begin{array}{c}\text { Total } \\
\text { Property }\end{array}$ & Larceny & Burglary & MVT \\
\hline 4 years before & $\begin{array}{l}-0.028 \\
(0.119)\end{array}$ & $\begin{array}{l}-0.112 \\
(0.170)\end{array}$ & $\begin{array}{l}-0.050 \\
(0.132)\end{array}$ & $\begin{array}{l}-0.019 \\
(0.208)\end{array}$ & $\begin{array}{l}-0.045 \\
(0.184)\end{array}$ & $\begin{array}{c}0.228 \\
(0.221)\end{array}$ & $\begin{array}{c}0.017 \\
(0.290)\end{array}$ \\
\hline 3 years before & $\begin{array}{c}0.062 \\
(0.102)\end{array}$ & $\begin{array}{c}0.034 \\
(0.133)\end{array}$ & $\begin{array}{c}0.065 \\
(0.082)\end{array}$ & $\begin{array}{c}0.036 \\
(0.168)\end{array}$ & $\begin{array}{c}0.014 \\
(0.155)\end{array}$ & $\begin{array}{c}0.179 \\
(0.142)\end{array}$ & $\begin{array}{c}0.127 \\
(0.234)\end{array}$ \\
\hline 2 years before & $\begin{array}{c}0.015 \\
(0.088)\end{array}$ & $\begin{array}{c}0.002 \\
(0.100)\end{array}$ & $\begin{array}{c}0.030 \\
(0.103)\end{array}$ & $\begin{array}{l}-0.041 \\
(0.164)\end{array}$ & $\begin{array}{l}-0.058 \\
(0.163)\end{array}$ & $\begin{array}{c}0.094 \\
(0.123)\end{array}$ & $\begin{array}{c}0.014 \\
(0.216)\end{array}$ \\
\hline $\begin{array}{l}1 \text { years before } \\
\text { (omitted) }\end{array}$ & & & & & & & \\
\hline 1 years after & $\begin{array}{c}0.243^{* * *} \\
(0.029)\end{array}$ & $\begin{array}{c}0.242^{* * *} \\
(0.053)\end{array}$ & $\begin{array}{c}0.319^{* * *} \\
(0.074)\end{array}$ & $\begin{array}{c}0.257^{* * *} \\
(0.058)\end{array}$ & $\begin{array}{c}0.243^{* * *} \\
(0.068)\end{array}$ & $\begin{array}{c}0.330^{* * *} \\
(0.064)\end{array}$ & $\begin{array}{c}0.243 \\
(0.163)\end{array}$ \\
\hline 2 years after & $\begin{array}{c}0.261^{* * *} \\
(0.049)\end{array}$ & $\begin{array}{c}0.298^{* * *} \\
(0.071)\end{array}$ & $\begin{array}{c}0.312^{* * *} \\
(0.109)\end{array}$ & $\begin{array}{c}0.309^{* * *} \\
(0.079)\end{array}$ & $\begin{array}{c}0.353^{* * *} \\
(0.073)\end{array}$ & $\begin{array}{c}0.276^{* * *} \\
(0.100)\end{array}$ & $\begin{array}{l}0.261^{*} \\
(0.153)\end{array}$ \\
\hline 3 years after & $\begin{array}{c}0.238^{* * *} \\
(0.067)\end{array}$ & $\begin{array}{c}0.281^{* * *} \\
(0.074)\end{array}$ & $\begin{array}{c}0.346^{* * *} \\
(0.122)\end{array}$ & $\begin{array}{c}0.270^{* * *} \\
(0.063)\end{array}$ & $\begin{array}{c}0.329^{* * *} \\
(0.057)\end{array}$ & $\begin{array}{c}0.154^{* *} \\
(0.071)\end{array}$ & $\begin{array}{c}0.143 \\
(0.125)\end{array}$ \\
\hline 4 years after & $\begin{array}{c}0.286^{* * *} \\
(0.089)\end{array}$ & $\begin{array}{c}0.412^{* * *} \\
(0.103)\end{array}$ & $\begin{array}{c}0.194^{* *} \\
(0.082)\end{array}$ & $\begin{array}{c}0.171^{* *} \\
(0.080)\end{array}$ & $\begin{array}{c}0.177^{* *} \\
(0.080)\end{array}$ & $\begin{array}{c}0.211^{* *} \\
(0.087)\end{array}$ & $\begin{array}{c}0.177 \\
(0.124)\end{array}$ \\
\hline 5 years after & $\begin{array}{c}0.435^{* * *} \\
(0.149)\end{array}$ & $\begin{array}{c}0.618^{* * *} \\
(0.132)\end{array}$ & $\begin{array}{c}0.273 \\
(0.188)\end{array}$ & $\begin{array}{l}0.375^{*} \\
(0.192)\end{array}$ & $\begin{array}{c}0.462^{* *} \\
(0.209)\end{array}$ & $\begin{array}{c}0.318^{* *} \\
(0.154)\end{array}$ & $\begin{array}{l}-0.161 \\
(0.326)\end{array}$ \\
\hline 6 years after & $\begin{array}{c}0.553^{* * *} \\
(0.192)\end{array}$ & $\begin{array}{c}0.761^{* * *} \\
(0.173)\end{array}$ & $\begin{array}{c}0.399 \\
(0.254)\end{array}$ & $\begin{array}{c}0.298 \\
(0.227)\end{array}$ & $\begin{array}{c}0.248 \\
(0.230)\end{array}$ & $\begin{array}{c}0.471^{* * *} \\
(0.181)\end{array}$ & $\begin{array}{l}-0.034 \\
(0.402)\end{array}$ \\
\hline 7 years after & $\begin{array}{c}0.778^{* * *} \\
(0.218)\end{array}$ & $\begin{array}{c}0.925^{* * *} \\
(0.219)\end{array}$ & $\begin{array}{c}0.734^{* *} \\
(0.295)\end{array}$ & $\begin{array}{c}0.609^{* *} \\
(0.268)\end{array}$ & $\begin{array}{l}0.499^{*} \\
(0.266)\end{array}$ & $\begin{array}{c}0.826^{* * *} \\
(0.235)\end{array}$ & $\begin{array}{c}0.312 \\
(0.518)\end{array}$ \\
\hline
\end{tabular}

Notes: Results from negative binomial models are reported. The number of observations in all models is 166293. All regressions include full set of control variables and month, year, state, and police station fixed effects as discussed in the text. Standard errors are clustered at the state level and reported in parenthesis. The signs $*{ }^{* *}$, and ${ }^{* * *}$ denote statistical significance at 10,5 , and 1 percent significance levels, respectively. 
Table 7. The effect of the repeal of Sunday alcohol bans on violent crimes committed on all days of the week

\begin{tabular}{|c|c|c|c|c|}
\hline Total Violent & $(1)$ & $(2)$ & $(3)$ & $(4)$ \\
\hline Treatment & $\begin{array}{c}-0.050^{* *} \\
(0.023)\end{array}$ & $\begin{array}{l}-0.029 \\
(0.032)\end{array}$ & $\begin{array}{c}-0.055^{* *} \\
(0.028)\end{array}$ & $\begin{array}{l}-0.039 \\
(0.036)\end{array}$ \\
\hline Marginal Effect for Treatment & $\begin{array}{c}-0.045^{* *} \\
(0.021)\end{array}$ & $\begin{array}{l}-0.027 \\
(0.029)\end{array}$ & $\begin{array}{c}-0.050^{* *} \\
(0.025)\end{array}$ & $\begin{array}{l}-0.035 \\
(0.032)\end{array}$ \\
\hline Predicted Number of Crimes & 0.928 & 0.924 & 0.929 & 0.926 \\
\hline $\begin{array}{l}\text { Incidence Rate Ratio } \\
\text { Assault }\end{array}$ & 0.951 & 0.971 & 0.947 & 0.962 \\
\hline Treatment & $\begin{array}{l}-0.035 \\
(0.039)\end{array}$ & $\begin{array}{l}-0.032 \\
(0.045)\end{array}$ & $\begin{array}{l}-0.030 \\
(0.045)\end{array}$ & $\begin{array}{l}-0.032 \\
(0.049)\end{array}$ \\
\hline Marginal Effect for Treatment & $\begin{array}{l}-0.018 \\
(0.021)\end{array}$ & $\begin{array}{l}-0.017 \\
(0.024)\end{array}$ & $\begin{array}{l}-0.016 \\
(0.024)\end{array}$ & $\begin{array}{l}-0.017 \\
(0.026)\end{array}$ \\
\hline Predicted Number of Crimes & 0.543 & 0.543 & 0.543 & 0.543 \\
\hline $\begin{array}{l}\text { Incidence Rate Ratio } \\
\text { Robbery }\end{array}$ & 0.966 & 0.968 & 0.970 & 0.968 \\
\hline Treatment & $\begin{array}{c}-0.080^{* *} \\
(0.031)\end{array}$ & $\begin{array}{l}-0.023 \\
(0.048)\end{array}$ & $\begin{array}{c}-0.080^{* * *} \\
(0.030)\end{array}$ & $\begin{array}{l}-0.032 \\
(0.039)\end{array}$ \\
\hline Marginal Effect for Treatment & $\begin{array}{c}-0.002^{* *} \\
(0.001)\end{array}$ & $\begin{array}{l}-0.001 \\
(0.001)\end{array}$ & $\begin{array}{c}-0.002^{* * *} \\
(0.001)\end{array}$ & $\begin{array}{l}-0.001 \\
(0.001)\end{array}$ \\
\hline Predicted Number of Crimes & 0.022 & 0.022 & 0.022 & 0.022 \\
\hline $\begin{array}{l}\text { Incidence Rate Ratio } \\
\text { Forcible Sex Crimes }\end{array}$ & 0.923 & 0.977 & 0.923 & 0.969 \\
\hline Treatment & $\begin{array}{c}0.019 \\
(0.032)\end{array}$ & $\begin{array}{c}0.057 \\
(0.038)\end{array}$ & $\begin{array}{c}0.020 \\
(0.030)\end{array}$ & $\begin{array}{c}0.053 \\
(0.036)\end{array}$ \\
\hline Marginal Effect for Treatment & $\begin{array}{c}0.001 \\
(0.001)\end{array}$ & $\begin{array}{c}0.001 \\
(0.001)\end{array}$ & $\begin{array}{c}0.001 \\
(0.001)\end{array}$ & $\begin{array}{c}0.001 \\
(0.001)\end{array}$ \\
\hline Predicted Number of Crimes & 0.024 & 0.024 & 0.024 & 0.024 \\
\hline Incidence Rate Ratio & 1.019 & 1.059 & 1.020 & 1.055 \\
\hline
\end{tabular}


Vandalism

\begin{tabular}{lcccc}
\hline Treatment & -0.046 & -0.011 & $-0.075^{*}$ & -0.028 \\
& $(0.047)$ & $(0.048)$ & $(0.045)$ & $(0.051)$ \\
Marginal Effect for Treatment & -0.012 & -0.003 & $-0.019^{*}$ & -0.007 \\
& $(0.012)$ & $(0.012)$ & $(0.011)$ & $(0.013)$ \\
Predicted Number of Crimes & 0.262 & 0.260 & 0.261 & 0.259 \\
Incidence Rate Ratio & 0.955 & 0.989 & 0.928 & 0.972 \\
\hline State-specific linear time trend & No & Yes & No & Yes \\
Model & Poisson & Poisson & Negative & Negative \\
& & & Binomial & Binomial \\
\hline
\end{tabular}

Notes: The number of observations in all specifications is 1663108. All regressions include full set of control variables and day of week, month, year, state, and police station fixed effects as discussed in the text. Predicted number of crimes is calculated for the treatment states before the repeal of the restrictions on Sunday alcohol sales. Standard errors are clustered at the state level and reported in parenthesis. The signs $*, * *$, and $* * *$ denote statistical significance at 10,5 , and 1 percent significance levels, respectively. 
Table 8. The effect of the repeal of Sunday alcohol bans on property crimes committed on all days of the week

\begin{tabular}{|c|c|c|c|c|}
\hline Total Property & $(1)$ & $(2)$ & $(3)$ & $(4)$ \\
\hline Treatment & $\begin{array}{c}-0.087^{*} \\
(0.051)\end{array}$ & $\begin{array}{c}0.021 \\
(0.066)\end{array}$ & $\begin{array}{c}-0.088^{*} \\
(0.039)\end{array}$ & $\begin{array}{c}0.001 \\
(0.068)\end{array}$ \\
\hline Marginal Effect for Treatment & $\begin{array}{l}-0.071^{*} \\
(0.042)\end{array}$ & $\begin{array}{c}0.017 \\
(0.056)\end{array}$ & $\begin{array}{c}-0.072^{* *} \\
(0.031)\end{array}$ & $\begin{array}{c}0.001 \\
(0.057)\end{array}$ \\
\hline Predicted Number of Crimes & 0.847 & 0.829 & 0.851 & 0.836 \\
\hline $\begin{array}{l}\text { Incidence Rate Ratio } \\
\text { Larceny }\end{array}$ & $0.917^{*}$ & 1.021 & $0.916^{* *}$ & 1.001 \\
\hline Treatment & $\begin{array}{l}-0.074 \\
(0.051)\end{array}$ & $\begin{array}{c}0.018 \\
(0.068)\end{array}$ & $\begin{array}{l}-0.081^{*} \\
(0.045)\end{array}$ & $\begin{array}{c}0.001 \\
(0.073)\end{array}$ \\
\hline Marginal Effect for Treatment & $\begin{array}{l}-0.042 \\
(0.029)\end{array}$ & $\begin{array}{c}0.011 \\
(0.040)\end{array}$ & $\begin{array}{l}-0.046^{*} \\
(0.025)\end{array}$ & $\begin{array}{c}0.000 \\
(0.043)\end{array}$ \\
\hline Predicted Number of Crimes & 0.592 & 0.581 & 0.594 & 0.584 \\
\hline $\begin{array}{l}\text { Incidence Rate Ratio } \\
\text { Burglary }\end{array}$ & 0.928 & 1.018 & $0.922^{*}$ & 1.001 \\
\hline Treatment & $\begin{array}{c}-0.122^{* * *} \\
(0.047)\end{array}$ & $\begin{array}{c}0.006 \\
(0.065)\end{array}$ & $\begin{array}{c}-0.113^{* * *} \\
(0.038)\end{array}$ & $\begin{array}{l}-0.002 \\
(0.061)\end{array}$ \\
\hline Marginal Effect for Treatment & $\begin{array}{c}-0.019 * * \\
(0.007)\end{array}$ & $\begin{array}{c}0.001 \\
(0.011)\end{array}$ & $\begin{array}{c}-0.018^{* * *} \\
(0.006)\end{array}$ & $\begin{array}{l}-0.000 \\
(0.010)\end{array}$ \\
\hline $\begin{array}{l}\text { Predicted Number of Crimes } \\
\text { Incidence Rate Ratio } \\
M V T\end{array}$ & $\begin{array}{c}0.166 \\
0.885^{* * *}\end{array}$ & $\begin{array}{l}0.162 \\
1.006\end{array}$ & $\begin{array}{c}0.166 \\
0.893^{* * *}\end{array}$ & $\begin{array}{l}0.162 \\
0.998\end{array}$ \\
\hline Treatment & $\begin{array}{l}-0.022 \\
(0.063)\end{array}$ & $\begin{array}{c}0.077 \\
(0.072)\end{array}$ & $\begin{array}{l}-0.028 \\
(0.059)\end{array}$ & $\begin{array}{c}0.063 \\
(0.066)\end{array}$ \\
\hline Marginal Effect for Treatment & $\begin{array}{l}-0.001 \\
(0.004)\end{array}$ & $\begin{array}{c}0.005 \\
(0.004)\end{array}$ & $\begin{array}{l}-0.002 \\
(0.003)\end{array}$ & $\begin{array}{c}0.004 \\
(0.004)\end{array}$ \\
\hline Predicted Number of Crimes & 0.059 & 0.058 & 0.060 & 0.059 \\
\hline Incidence Rate Ratio & 0.978 & 1.080 & .9722 & 1.065 \\
\hline
\end{tabular}




\begin{tabular}{lcccc}
\hline State-specific linear time trend & No & Yes & No & Yes \\
Model & & & Negative & Negative \\
& Poisson & Poisson & Binomial & Binomial \\
\hline
\end{tabular}

Notes: The number of observations in all specifications is 1663108. All regressions include full set of control variables and day of week, month, year, state, and police station fixed effects as discussed in the text. Predicted number of crimes is calculated for the treatment states before the repeal of the restrictions on Sunday alcohol sales. Standard errors are clustered at the state level and reported in parenthesis. The signs $*, * *$, and $* * *$ denote statistical significance at 10,5 , and 1 percent significance levels, respectively. 
Figure 1. Trends in total violent crimes in treatment and control states

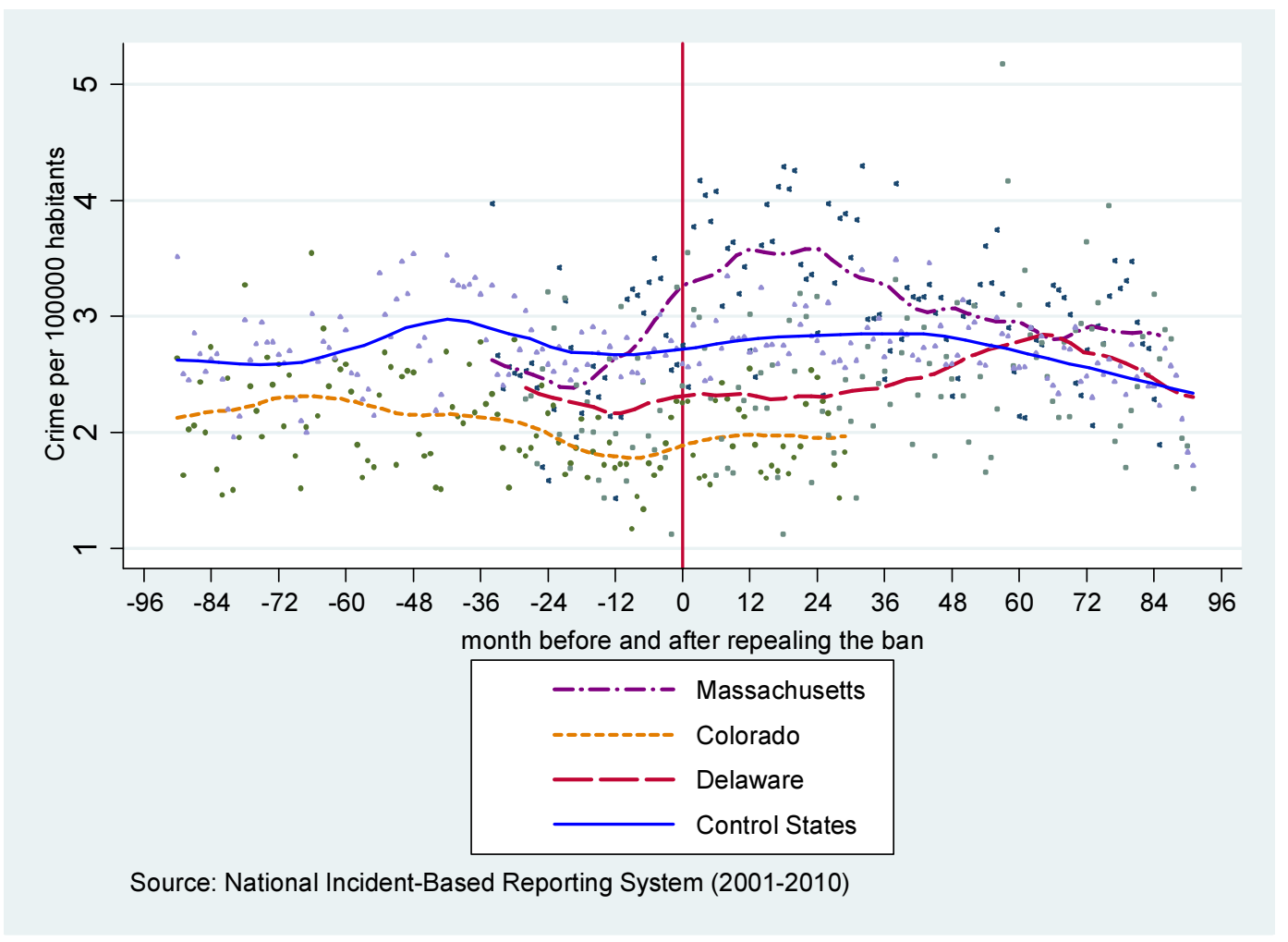

Notes: The Epanechnikov kernel-weighted local polynomials for the total number of violent crimes per 100000 people are plotted for treatment and control states before and after the repeal of the Sunday alcohol sales ban. The figure is centered in the month and year the policy became effective in each of treatment states (time 0 ). 
Figure 2. Trends in total property crimes in treatment and control states

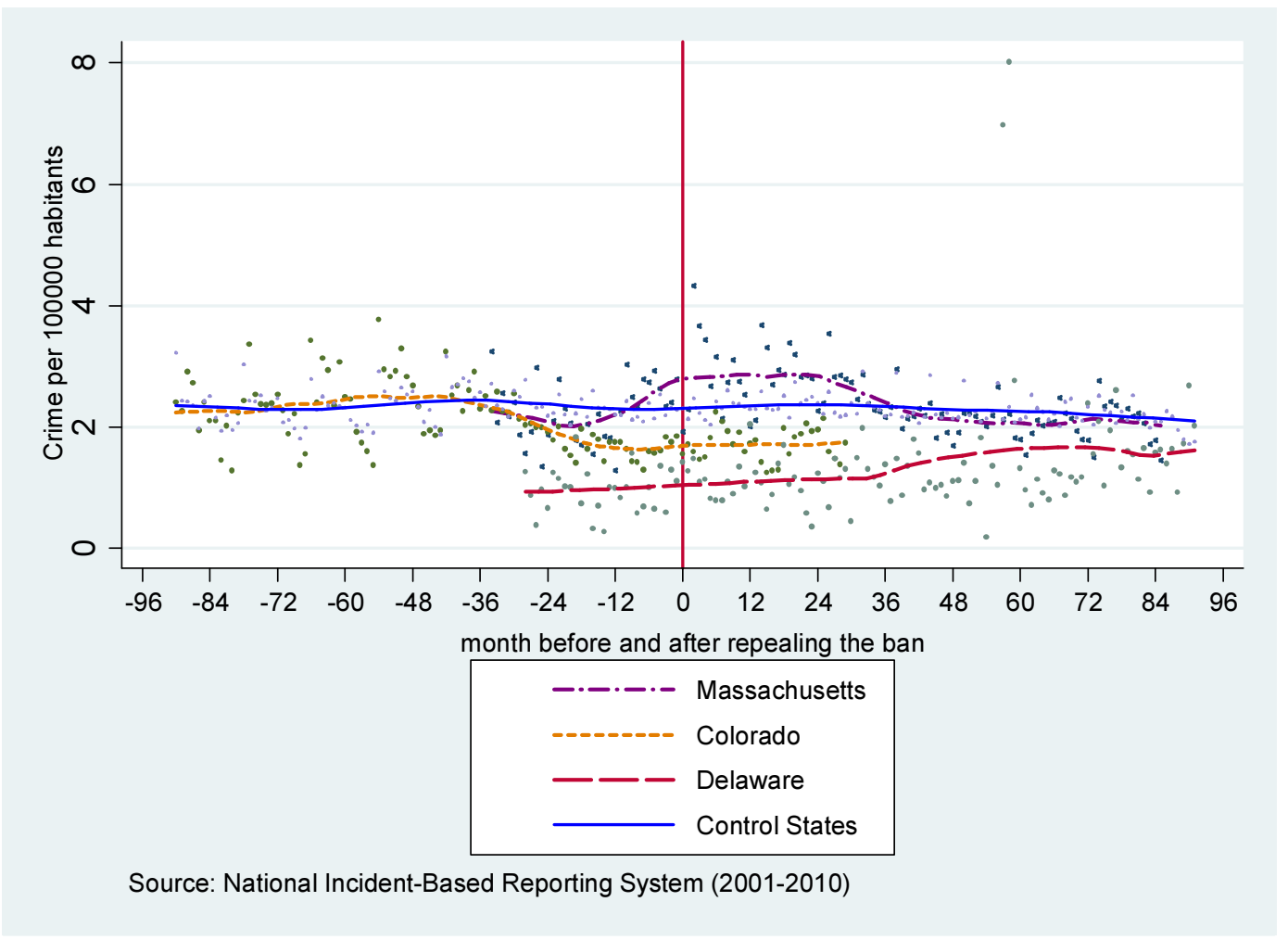

Notes: The Epanechnikov kernel-weighted local polynomials for the total number of property crimes per 100000 people are plotted for treatment and control states before and after the repeal of the Sunday alcohol sales ban. The figure is centered in the month and year the policy became effective in each of treatment states (time 0 ). 


\section{Appendix}

Table A1. Summary statistics for treatment and control states

\begin{tabular}{lcccc}
\hline & No. of obs. & $\begin{array}{c}\text { No. of police } \\
\text { agencies }\end{array}$ & Year & Date of repeal \\
\hline $\begin{array}{l}\text { Treatment states } \\
\text { Colorado }\end{array}$ & 225723 & 28 & $2000-2010$ & $7 / 1 / 2008$ \\
Delaware & 60258 & 6 & $2001-2010$ & $5 / 15 / 2003$ \\
Massachusetts & 275739 & 47 & $2000-2010$ & $11 / 26 / 2003$ \\
Control States & 121629 & 21 & $2000-2010$ & \\
Connecticut & 465714 & 43 & $2000-2010$ & \\
South Carolina & 410913 & 44 & $2000-2010$ & \\
Tennessee & 186273 & 20 & $2000-2010$ & \\
Utah & & & & \\
\hline
\end{tabular}

Notes: The date of repeal refers to the exact date that a particular state repealed its ban on Sunday sales of all alcoholic beverages at off-premise locations. The year refers to data period that NIBRS provides daily crime data for all months. 